\title{
Serological evidence of antibodies to certain arboviruses in desert rodent sera in Egypt
}

\author{
Nour El.Din H. Sherif \\ Zoology Department, Faculty of Science, Suez Canal University, Ismailia, Egypt
}

\begin{abstract}
Introduction : Small rodents inhabiting the wadis close to St Katherine in the mountains of the Sinai Peninsula, Egypt, were trapped and antibodies to Sindbis (SIN), West Nile (WN) and Quaranfil (QRF) viruses in their sera were studied.

Materials and Methods One mouse had Haemagglutination-inhibition (HI) antibodies against SIN antigen in his serum, 3 mice had $\mathrm{HI}$ antibodies against WN antigen in their sera. The titers is low to be of any significance.

Conclusion: It seems that natural cycle of transmission of SIN and WN viruses involving rodents does not exist. Seven mice had Complement-fixation (CF) antibodies in their sera against Quaranfil antigen. Conclusion, the CF test results suggest the existence of another mammal vector cycle.
\end{abstract}

Keywords: Sindbis, West Nile and Quaranfil viruses (rodent), HI, CF.

\section{Introduction}

Like several other mammals rodents get natural infection with an arthropodborne viruses (arboviruses) without showing apparant ill health, and natural infection is detected during surveys accidentally by virus isolation or serologic tests. Rodents act as a subsidiray natural host for the tickborne group of viruses (Kuceruk , 1963\& Webb, 1965) and were thought to play a role in the natural cycle of propagation of Rift valley fever virus (Weinbren and Mason,1957); Bunyamwera virus (Simpson,1965); Venezuelan equine encephalitis virus and group $\mathrm{C}$ arboviruses (Jonkers et al., 1968). Experimental virus infection of rodents lead to the development of viremia, some animals died while the majority survived and acquired antibodies to the arbovirus used (Simthburn \& Haddaw, 1949 Weinbern \& Mason , 1957 Simpson, 1965 and ,1966).

In Egypt the prevelant species of rodents (Hoogstraal, 1963) live in close association of human population in the cultivation fields. Their relation to the natural cycles of propagation of arboviruses known to be in active circulation in Sinai, Egypt was not studied. The viruses recognized as endemic in Egypt are mosquito-borne Sindbis (Taylor et al.,
1955) ,West Nile (Taylor et al .,1956), Sandfly (Schmidt et al., 1966), The tick borne Quaranfil, Chenuda and Nyamanini viruses (Taylor et al.,1966c) .Sandfly virus infects humans only, but the other viruses most probably are mainly zoonosis .

This paper describes antibody studies on desert rodent sera collected in various regions of St Katherine's Protectorat, Egypt, to investigate the occurrence of natural infection of these rodents with Sindbis, West Nile or Quaranfil viruses.

\section{Materials and Methods}

\section{Study sites:}

The study was carried out in the St Katherine's Protectorate, southern Sinai, an arid montane region characterized by complex systems of dry valleys (Wadis) and plains (Hobbs, 1995; Zalat \& Gilbert, 1998; Behnke et al., 2000). Four wadies were choosen: El Arbaein and Tofaha, close to the Suez Canal University Environmental Research Centre (ERC) at St Katherine (Behnke et al., 2000) and Abu Seila and Boqueia, some $5 \mathrm{~km}$ to the north across the Plain of El Raha (Barnard et al., 2003b) . Collection of rodents : 
Mice were trapped in each wadi during August and September 2001 using Sherman small mammal traps (H.C.Sherman InC., Tallahassee, USA).

\section{Rodent Sera Collection :}

All traps were brought into the ERC at St Katherine where the animals were removed and identified according to Osborn and Helmy (1980). Trapped animals were culled $(40 \%$ of the catch by agreement with the St Katherine National Protectorate authorities and blood samples were taken by cardiac puncture. Blood samples were centrifuged and the resulting serum frozen at $-20^{\circ} \mathrm{C}$. until tested.

\section{Viruses:}

Quaranfil (QRF) virus (strain At 1113) P11, Sindbis (SIN) virus (strain Egypt Ar-339) P39 and West Nile (WN) virus (Strain Egypt 101) P8 were inoculated intracerebrally into suckling mice to prepare virus stocks.

\section{Preparation of viral antigen :}

For haemagglutination- inhibition (HI) and complement-fixation (CF) tests antigents were prepared by the sucroseacetone methods (Clarke and Casals, 1958). Except for QRF the antigens were used in HI tests.QRF antigen were done by the $\mathrm{CF}$ test.

\section{Serologic tests:}

Haemagglutinatien-inhibition test : serum samples were adsorped with acidwashed kaolin at $\mathrm{pH} 9$ to remove non- specific inhibitors (Clarke and Casals, 1958) and then were tested by the microtitration method.

Complement-fixation test: The $\mathrm{CF}$ was done by the micro- adaptation of the laboratory Branch complement-fixation (LBCT) test (Casey,1965) using four units of complement, the sera were inactivated for 20 minutes at $60^{\circ} \mathrm{C}$ and were used or treated by $\mathrm{Co}_{2}$ dry ice if found to be anticom-plementary (lmam and Alfy, 1966 ) then used.

\section{Results}

Rodents collected from study sites:

The following are the numbers and species of animals collected:

71 Acomys cahirinus dimidiatus, 18 Dipodyllus daosyurus dasyurus, 7 Elicomys quercinus melanurus, 2 sekeetamys calurus calurus, 4 Acomys reunatus russatus, 1 Mus musculus.

The Acomys cahirinus diamidiatus was the most frequent species of the different mice captured.

\section{Antibodies to arboviruses:}

The results of serological Haemagglutination-inhibition and complement-fixation tests are summarized in Table 1

Only one mouse serum had HI antibodies against Sindbis antigen. Three mice sera had HI antibodies against West Nile antigen Seven mice sera had CF antibodies against Quranfil antigen.

Table( 1): Arboviruses antibodies in rodent sera

\begin{tabular}{|c|c|c|c|c|c|}
\hline \multirow{3}{*}{ Animal } & \multirow{3}{*}{ Sera tested } & \multicolumn{4}{|c|}{ number reactive sera and antibodies titers } \\
\hline & & $\mathrm{HI}$ & HI & & $\overline{\mathrm{CF}}$ \\
\hline & & Sindbis & West Nile & & Iranfil \\
\hline Acomys dimidialus & 71 & $11 / 10$ & $11 / 10$ & 5 & $1 / 10$ \\
\hline Dipodillus dasyurus & 18 & 0 & $\begin{array}{ll}1 & 1 / 10\end{array}$ & 1 & $1 / 10$ \\
\hline Eliomus quercinus & 7 & 0 & 0 & & 0 \\
\hline Sp\&eetamus calurus & 2 & 0 & $\begin{array}{ll}1 & 1 / 10 \\
\end{array}$ & & 0 \\
\hline Acomys ressatus & 4 & 0 & 0 & 1 & $1 / 10$ \\
\hline Mus nusculus & 1 & 0 & 0 & & 0 \\
\hline
\end{tabular}




\section{Discussion}

Egypt as a country in the subtropical area, has diverse ecological settings whereby there are haematophagous arthropods which feed upon man and animals. In addition, there are large varieties, of wild free living and migratory birds (Hoogstraal et al., 1961, 1963, $1964 \&$ \& 1968) as well as free living small mammals (Hoogstraal, $1956 \&$ 1963) that are known to act as reservoirs for several arboviruses (Simpson, 1969 and Hoogstraal, 1973) .

There are 31 arboviruses reported from Egypt. Eight of the 31 have been demonstrated, or are believed to be transmitted by mosquitoes, 16 by ticks and 3 by phlebotomus sandflies, the vectors of 4 are unknown (Darwish and Hoogstraal, 1981).

Rodents live in close association of human population in the cultured fields . On basis of information gathered from the current literature, the relation of rodents to the natural cycles of propagation of arboviruses known to be in active circulation in Sinai, Egypt was not studied .

The two main endemic arboviruses in Egypt are the mosquito-borne Sindbis (Taylor et al., 1955) and West Nile (Taylor et al., 1956).

West Nile (WN) virus was isolated ${ }^{1}$ from patients, birds and mosquitoes in Egypt in the Early 1950's (Melnick et al., 1991 and Taylor et al., 1956). The virus was soon recognized as the most widespread flaviviruses.

This study showed that the number of rodent sera with antibodies against WN virus is small and the titer is low to be of any significance. It seems that the natural cycle of transmission of WN virus involving rodents does not exist.

Sindbis (SIN) virus (Togaviridae, alphavirus) was first isolated from Culex mosquitoes (probably $C$. univittatus) and birds from Sindbis village, Qalyubia, Egypt (Taylor, et al., 1955).

The results showed only one rodent sera had HI antibodies against Sindbis antigen. Antibodies to SIN virus are almost absent from rodent sera which may be due to that mosquitoes transmitting SIN virus do not bit rodents. The results showed that SIN virus does not naturally affect rodents in Egypt.

Quaranfil (QRF) virus was first recovered from the blood of a febrile child (Taylor et al., 1956) who lived in a Quaranfil village north of Cairo nearby the arboreal rookeries of the common cattle herons also it was isolated from Argas ticks (Taylor et al., 1966 c). Retrospectively the vector of this virus was identified as the heron Argas ticks Argas arboreus (Kaiser et al., 1964). Field collections of A. arboreus on repeated occasions yielded QRF virus (Kaiser, 1966a) .Ecologically QRF virus appeared as a bird adapted virus (Kaiser et al., 1964) transuitted by A. arboreus, a restricted vecor (Hoogstraal , 1973).

7 Out of 103 wield-cought rodent sera were founds to have QRF antibodies suggested) that QRF virus among several viruses responsible for rodent infection.

In the present study it would appear that the CF test results obtained with rodent sera suggest the existence of another mammal vector cycle.

\section{References}

1. Barnard CJ, Sayed E, Barnard LE, Behnke JM, Abdel Nabi I, Sherif N, Shutt A \& Zalat S (2003b): Local variation in helminth burdens of Egyptian spiny mice (Acomys cahirinus dimidiatus) from ecologically similar sites: relationships with hormone concentrations and social behaviour.J.Helminthol.77:197-207.

2. Behnke JM, Barnard CJ, Mason N, Harris PD, Sherif NE, Zalat $S$ \& Gilbert FS (2000) : Intestinal helminthes of spiny mice (Acomys cahirnius dimidiatus) from St Katherine's protectorate in the Sinai, Egypt. J.Helminthol.74:31-44.

3. Casey HL (1965) :Standardized diagnostic complement fixation method and adaptation to micro-test.Pbl.Heth Monogr. 74:34.

4. Clarke DH and Casals J (1958): Techniques for haemagglutination and haemagglutination-inhibition with arthropod - borne virus. Am.J Trop. Med. Hyg. 7 : 561- 573.

5. Darwish MA and Hoogstraal H (1981): Arboviruses infecting humans and lower animals in Egypt: A review of thirty years 
of research .J.Egypt .Publ.Health Assoc. LVI (1 \& 2 ):

6. Hobbs JJ (1995) : Mount Sinai, University of Texas press, Austin, Texas.

7. Hoogstraal H (1956) : African Ixodoidea. I. Ticks of the Sudan (with special reference to Equatoria province and with preliminary reviews of the genera Boophilus, Margaropus and Hyalomma). Department of the Navy Bureau of Medicine and Surgery, Washington, D.C.

8. Hoogstraal H (1963): A brief review of the contemporary land mammals of Egypt (including Sinai) 2. Logomorpha and todentia .J.Egypt Publ. Health Assoc.38:1 - 35 .

9. Hoogstraal H (1973): Viruses and ticks. In:viruses and invertebrates, Chap.18, pp. $349-390$. Edited by A.J. Gibbs. NorthHolland publishing Company, Amsterdam, London.

10. Hoogstraal H, Kaiser MN, Seymour C (III) and Gaber S (1968) : Noteworthy recent tick records from Egypt 1. Ixodes arboricola Schulze and Schlottke infesting resident migrant, and wintering birds in the Western coastal desert. J.Egypt. Publ.Hlth Assoc. 42:223-229.

11. Hoogstraal H, Kaiser MN,Traylor MA,Gaber S and Guindy E (1961): Ticks (Ixodoidea) on birds migrating from Africa to Europe and Asia. Bull. World Health Organ .24:197-212.

12. Hoogstraal H, Kaiser MN, Traylor MA,Guindi E and Gaber S (1963): Ticks (Ixodoidea) on birds migrating from Europe and Asia to Africa, 1959-61.Bull world Health Organ.28:235-262.

13. Hoogstraal H,Traylor MA, Gaber S , Malakatis G, Guindy $E$ and Helmy I (1964): Ticks (Ixodidae) on migrating birds in Egypt,spring and fall 1962. Bull.World Health Organ. 30 : 355 - 367.

14. Imam ZEI and Alfy L (1966): The elimination of the anticomplementary reactions of the sera by $\mathrm{CO}_{2}$. J.Egypt.Publ Health Assoc. 41 : 33 - 36.

15. Jonkers, AH, Spence L, Downs W G, Aitken THG and Worth CB (1968): Arboviruses studies in Bush Bush Forest,Trinidad W.I.Sept.1959-Dec. 1964 .VI Rodent associated viruses (VEE and agents of group $\mathrm{C}$ and Guama) Isolation and further studies. Am. J. Trop. Med. Hyg. 17:285-298.

16. Kaiser MN (1966a) : Viruses in Ticks. 1. Natural infections of Argas (persicargas) arboreus by Quaranfil and Nyamamini viruses and absence of infections in A.(p.) persicus in Egypt. Am.J.Trop.Med.Hyg. 15 : 964-975.
17. Kaiser MN, Hoogstraal $H$ and Kohls GM (1964): The subgenus persicargas, new subgenus (Ixodoidea, Argasidae, Argas).1.A.(p.)arboreus ,new species, an Egyptian persicus like parasite of wild birds, with a redefinition of the subgenus Argas.Ann.Ent.Soc.Am.57:60-69.

18. Kuceruk VV (1963): Rodents in relation to problems of arthropodborne diseases. Bull. World Health Organ. 29:25-29.

19. Melnick JL, Paul JR, Riordan JT, Barnett, VH, Goldblum $N$ and Zabin E (1951): Isolation from human sea in Egypt of a virus apparently identical to West Nile virus. Proc.Soc.Exp.Biol.Med.77:661- 665.

20. Osborn DJ and Helmy I (1980): The contemporary land mammals of Egypt (including Sinai),Fieldiana Zoology Published by Field Museum of Natural History, New Series.No.5:1-579.

21. Schmidt JR, Schmidt ML and McWilliams JG (1960): Isolation of Phlebotomus fever virus from Phlebotomus papatasi.Am.J.Trop.Med.Hyg. 9 : 450-454.

22. Simpson DIH (1965): Experimental Bunyamwera virus infection in two species of African rats. Trans. R. Soc. Trop. Med. Hyg.59 : 198 - 204.

23. Simpson DIH (1966): The susceptibility of Arvicanthis (Rupell) to infection with various arboviruses. Trans R.Soc. Trop. Med. Hyg.60:248-254.

24. Simpson DIH (1969): Arboviruses and free living wild animals .Symp. Zool. Soc. London. 24 : 13 -28.

25. Simthburn KCand Haddaw AJ(1949): African wild animals and yellow fever II Rodents ,Bush pig, Hyrae and Leopard. Am.J.Trop.Med.Hyg.29:409- 423.

26. Taylor RM, Hurlbut HS, Work TH, Kingston RJ and Forthingham TE (1955): Sindbis virus: A newly recognized arthropod- transmitted virus. Am. J. Trop. Med. Hyg. 4:844-862.

27. Taylor RM, Hurlut HS, work TH, Kingston RJ and Hoogstraal H (1966c): Arboviruses isolated from Argas Ticks in Egypt: Quaranfil, Chenuda and Nyamanini, Am. J. Trop. Med. Hyg. 15:76-86.

28. Taylor RM, Work TH, Hurlbut HS and Rizk F (1956): A study of the ecology of West Nile virus in Egypt. AM.J.Trop.Med.Hyg.5:579-260.

29. Webb HE (1965): Kyasanur forest disease virus in three species of rodents. Trans.Roy.Soc.Trop.Med.Hyg.59:205- 211.

30. Weineren MP and Mason PJ (1957): Rift vally fever in a wild field rat (Arvicanthis abyssinicus): A possible natural host. S. Afr. Med. J. 31:427-430. 
31. Zalat S \& Gilbert FS (1998): A walk in (the Blue Pool), Cairo, El Haramen Press. the Sinai : St Katherine to Al Galt al Azraq

دليل بالمصول عن أجسام مضادة لفيروسات منقولة بالمفصليات في أمصال

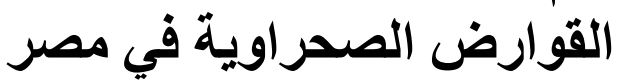

نور الدين حسين صالح شريف

قسم علم الحيو ان - كلية العلوم - جامعة قناة السويس ـ الإسماعيلية

في هذه الدر اسة تم اصطياد القوارض (الفئران) الصغيرة التي تسكن الوديان القريبة من

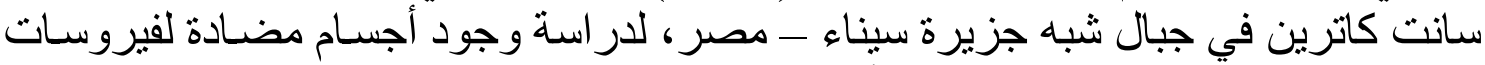
السندبيس و الوست نيل و القر انفيل في في أمصالها.

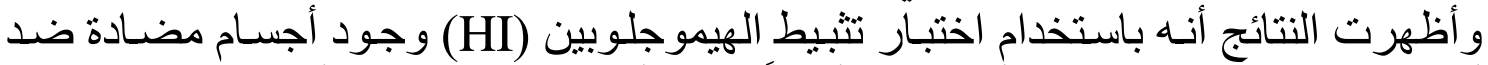

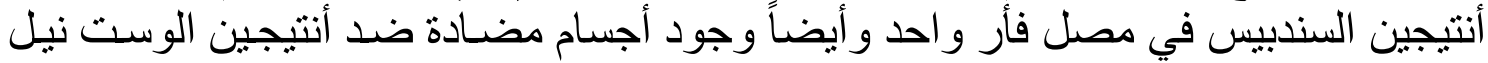

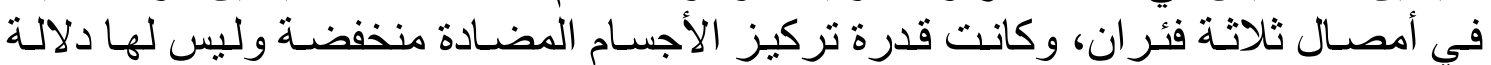

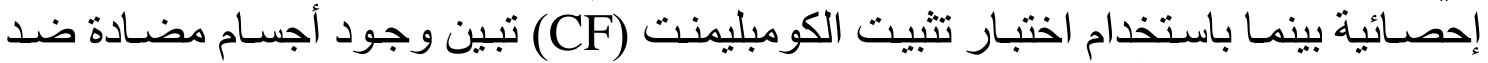
أنتيجين القر انفيل في أمصال سبعة فئران النيان.

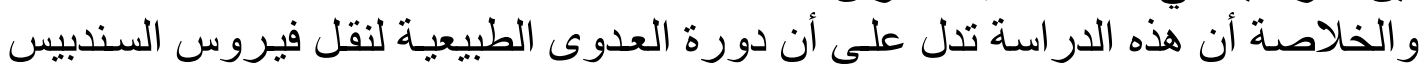

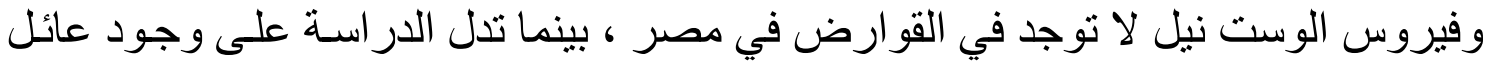
وسيط ثدي ينقل العدوي في الطبيعة لفيروس القر انفيل. 